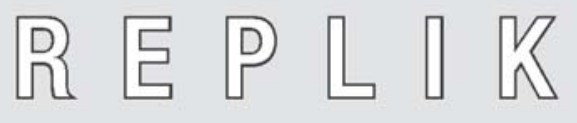

\title{
til Jens Tonboes "Balanceproblemer?"
}

\section{af Linda Nielsen, Formand for Familie- og Arbejdslivskommissionen}

Jeg vil gerne indlede med at slå fast, at når kommissionen i sin rapport fokuserer på børnefamiliernes balanceproblemer, så er det på baggrund af et stort analysearbejde, hvor alle livsfaser er blevet gennemgået med henblik på at kortlægge, hvor balanceproblemerne er størst. Kommissionens analyser viser, at det særligt er børnefamilierne og de enlige forsørgere, som har de største problemer med at finde en god balance mellem familie- og arbejdslivet. Dette fokus ligger naturligt i forlængelse af kommissionens kommissorium, hvoraf det fremgår, at kommissionen skal fokusere på de grupper, hvor behovet er størst.

Andre grupper - for eksempel studerende eller ældre medarbejdere - kan selvsagt også opleve balanceproblemer. Men det er klart hos børnefamilierne og de enlige forsørgere, at de største balanceproblemer er. I den forbindelse har det også været vigtigt for kommissionen at se på balanceproblematikken fra børnenes perspektiv.

Derudover skal det med i billedet, at en stor del af danskerne rent faktisk har en god balance mellem familie- og arbejdslivet. Der synes således ikke i dokumentationen at være baggrund for at lave grundlæggende om på den måde, vi i Danmark har indrettet vores familie- og arbejdsliv på.

Den bagvedliggende præmis for Tonboes kommentarer til rapporten synes at være, at det er ved at arbejde mindre, at man skaber bedre balance mellem familie- og arbejdslivet. I forlængelse heraf påstås, at kommissionens anbefalinger ikke vil med til at skabe mere balance, men blot vil få os til at arbejde mere.

Den første præmis - at det er ved at arbejde mindre at vi løser balanceproblemerne - skyder helt forbi målet. Den anden påstand - at kommissionens anbefalinger vil få os til at arbejde mere - er helt forkert.

Med hensyn til spørgsmålet om, hvorvidt vi skal arbejde mere eller mindre, så har det været afgørende for kommissionens arbejde, at vi med de nuværende konjunkturer og de kommende store ældregenerationer ganske sim- 
pelt ikke har råd til at arbejde mindre, hvis vi skal finansiere vores velfærdssamfund. Det fremgår tydeligt af en lang række analyser, blandt andet fra Velfærdskommissionen. Der var intet nemmere for kommissionen end at foreslå en 30-timers uge for at give mere tid til familien, men det har vi ganske simpelt ikke råd til.

Omvendt har det heller ikke været kommissionens ønske at vi skal arbejde mere. Tværtimod har det været en vigtig pointe i kommissionens arbejde, at vi skal arbejde anderledes, hvis vi skal have bedre tid og overskud til familien.

For at give bedre muligheder for at arbejde på en anden måde har kommissionen udviklet en række forskellige anbefalinger. Kommissionen anbefaler blandt andet, at man indfører en flekskonto, der skal give bedre mulighed for at arbejde mindre, for eksempel mens man har små børn, mod til gengæld at arbejde mere på tidspunkter, hvor det passer bedre, for eksempel når børnene ikke længere bor hjemme. Med Flekskontoen får den enkelte bedre mulighed og større fleksibilitet i forhold til at tilrettelægge arbejdslivet på en mere balancevenlig måde. En anden af kommissionens anbefalinger er rettet mod arbejdspladserne, der i højere grad opfordres til at sætte eksplicitte grænser for det grænseløse arbejde, for eksempel ved klart at signalere at ferie er ferie. Der bliver stadigt flere, som får grænseløst arbejde, og følelsen af altid at "være på" stresser mange danskere. Der er derfor behov for, at arbejdspladserne spiller en større rolle, hvis vi skal arbejde på en anden og mere balancefremmende måde.

Tonboes anden påstand - at kommissionens anbefalinger skulle få os til at arbejde mere - er grebet ud af den blå luft. En lang række af kommissionens anbefalinger vil tværtimod helt oplagt bidrage til at styrke sammenholdet i familierne ved at øge den tid, vi bruger sammen i familien. For eksempel vil kommissionens anbefalinger give forældre bedre muligheder for at passe deres syge børn. Dette vil styrke familiens sammenhold og fundament, når forældrene bliver hjemme med god samvittighed i stedet for at sende et barn i daginstitution, før barnet måske er helt raskt. Derudover foreslår kommissionen, at man giver tilskud til de praktiske opgaver i hjemmet. Hermed får familierne mulighed for at udlicitere en opgave i hjemmet, som for mange er et irritationsmoment, og som tager tid fra et mere meningsfyldt samvær med familien.

Alt i alt deler jeg slet ikke Tonboes pessimisme i forhold til, om vi fremover kommer til at arbejde mere. Tværtimod vil kommissionens anbefalinger være en god fremtidssikring i forhold til at arbejde på en mere familie- og balancevenlig måde og dermed forebygge nogle af de stigende samfundsproblemer vi oplever, ikke mindst i forhold til stress.

Linda Nielsen

E-mail: Linda.Nielsen@jur.ku.dk 